\title{
Perbandingan Metode Single Exponential Smoothing dan Metode Holt untuk Prediksi Kasus COVID-19 di Indonesia
}

\author{
Nur Hijrah As Salam Al Ihsan ${ }^{1}$, Hanifah Hanun Dzakiyah ${ }^{2}$, Febri Liantoni ${ }^{3}$ \\ 1,2,3 Pendidikan Teknik Informatika dan Komputer, Fakultas Keguruan dan Ilmu Pendidikan, \\ Universitas Sebelas Maret, Surakarta, Indonesia \\ ${ }^{1}$ hijrahassalam@gmail.com \\ ${ }^{2}$ hanifahhanun24@gmail.com \\ ${ }^{3}$ febri.liantoni@gmail.com
}

Diterima 26 Juni 2020

Disetujui 23 November 2020

\begin{abstract}
Coronavirus disease (COVID-19) was first discovered in December 2019 in Wuhan, China, and spread so quickly into a pandemic. This outbreak has spread to 24 other countries, including Indonesia. Its spread is very fast, so a co-19 prediction study is needed to be able to make the right policy. To be able to predict the number of COVID-19 cases can be done with the Forecasting Technique. The purpose of this study is to forecast and compare Single Exponential Smoothing and Double Exponential Smoothing $\neg$ against the number of COVID-19 cases in Indonesia. The results of this study can be used as consideration for policymaking in dealing with the spread of COVID-19. Distribution predictions are based on data released by the Indonesian National Disaster Management Agency (BNPB) in the first 100 days of COVID-19 deployment. The results of this study are the Double Exponential Smoothing method is more accurate than the Single Exponential Smoothing method because the forecasting results show an increase from the previous data. And the percentage of errors (MAPE) obtained is significantly smaller.
\end{abstract}

Index Terms-coronavirus, COVID-19, exponential smoothing, forecasting, Holt

\section{Pendahuluan}

Coronavirus Disease (COVID-19) pertama kali diidentifikasi pada Desember 2019 di Wuhan, China, dan menyebar cepat ke 24 negara lain. Virus ini menyebar sangat cepat, studi terbaru menunjukkan bahwa virus ini dapat ditransmisikan dari manusia ke manusia melalui droplets [1]. Sejak maret 2020 oleh Organisasi Kesehatan Dunia menetapkan COVID-19 sebagai sebuah pandemic. Sampai sejauh ini, secara global COVID-19 sudah menginfeksi 5,380,970 dan menjadi masalah Bersama yang dihadapi oleh penduduk dunia di tahun ini.

Kasus positif COVID-19 pertama Indonesia ditemukan pada Maret 2020 dan terus menyebar hingga menjadi 18,010 kasus pada 18 April 2020 [2]. Indonesia sebagai negara yang ikut terinfeksi virus ini, harus menerapkan beberapa protocol kesehatan seperti memakai masker, karantina wilayah, mencegah kerumunan massa, mencuci tangan, dan melakukan kegiatan dirumah. Kasus virus corona di Indonesia pada saat ini belum menunjukkan kurva melandai. Presentase kasus corona masih belum stabil, dan masil terjadi fluktuasi. Data yang dihimpun oleh Badan Nasional Penanggulangan Bencana (BNPB) menunjukkan jumlah pasien positif corona per $27 \mathrm{Mei}$ 2020 adalah 23.851 orang. Bertambah 686 orang atau 2,96\% dibandingkan posisi per hari sebelumnya. Dalam 14 hari terakhir, rata-rata kenaikan kasus corona di Indonesia adalah 3,16\% per hari. Masih di atas rata-rata global yaitu $2,01 \%$ per hari. Hal ini menunjukkan diperlukannya penanganan lebih lanjut dalam menahan laju penyebaran virus corona ini.

Salah satu langkah yang bisa digunakan untuk membantu mengatasi wabah virus COVID-19 ini yaitu melalui prediksi jumlah penderita. Proses prediksi ini dapat digunakan untuk pertimbangan dalam mengambil kebijakan dan strategi yang diambil dalam penanganan wabah ini. Prediksi adalah sebuah kebutuhan dalam menentukan strategi yang tepat untuk dapat melewati masa kritis ini, dengan prediksi yang mendekati tepat maka kebijakan yang tepat juga dapat segera diambil. Salah satu metode yang dapat digunakan untuk prediksi yaitu Exponential Smoothing.

Exponential smoothing adalah perkembangan dari moving average, yang sering digunakan untuk menyelesaikan masalah data time series [3]. Peramalan dalam Exponential Smoothing dilakukan secara mengulang perhitungan secara terus menerus dengan menggunakan data terbaru, dimana nilai yang lebih baru diberikan bobot yang relatif lebih besar dibandingkan nilai pengamatan yang lebih lama. Dalam studi kasus moving average, bobot yang dikenakan pada nilai-nilai pengamatan merupakan hasil sampingan dari sistem yang diambil. Tetapi dalam Exponential Smoothing, terdapat satu atau lebih parameter pemulusan yang ditentukan secara jelas dan 
hasil pilihan ini menentukan bobot yang dikenakan pada nilai pengamatan. Exponential Smoothing memiliki tiga tipe yaitu single, double, triple. Pada penelitian sebelumnya diketahui bahwa metode Double Exponential Smoothing memiliki nilai error yang lebih kecil dari pada single maupun Triple Exponential Smoothing [4], [5]. Pada Double Exponential Smoothing terdapat dua tipe penyelesaian yaitu Brown dan Holt. Pada penelitian sebelumnya mengenai pembandingan metode Brown dan Holt diperoleh hasil penyelesaian metode dari Brown memberikan nilai kesalahan peramalan lebih kecil dibandingkan penyelesaian dari Holt untuk semua kriteria yang diujikan[6], [7].

Pada penelitian sebelumnya yang telah dilakukan, penulis menggunakan metode Double Exponential Smoothing untuk memprediksi nilai bitcoin dalam pengambilan keputusan dalam perdagangan. Pada penelitian ini diperoleh nilai alpha 0.9 sebagai nilai terbaik [8]. Pada peneltian ini dilakukan perbandingan metode Single Exponential Smoothing dan metode Holt untuk prediksi kasus COVID-19 di Indonesia.

\section{TINJAUAN PUSTAKA}

\section{A. Forecasting}

Forecasting atau Peramalan yang menjadi fokus pada penelitian ini merupakan salah satu bagian terpenting dalam meningkatkan efisiensi dan efektifitas pada perencanaan sekaligus bagian integral pada pengambilan keputusan [9]. Pada peramalan ini, peneliti menentukan solusi dari masalah yang akan diselesaikan dengan memperkirakan faktor mana saja yang berpengaruh pada hasil yang akan dicapai.

\section{B. Metode Single Exponential Smoothing}

Metode ini merupakan metode yang menunjukkan penurunan pembobotan secara eksponensial terhadap nilai observasi yang lebih terdahulu dengan memberikan nilai yang relatif lebih besar dibandingkan nilai pada observasi yang sudah pernah dilakukan sebelumnya [10]. Pada penggunaan metode ini tidak berpengaruh pada trend dan musim dengan rumus sebagai berikut:

$$
S_{t}=\alpha X_{t}+(1-\alpha) S_{t-1}
$$

Di mana: $S_{t}$ merupakan nilai peramalan pada periode berikutnya, $X_{t}$ merupakan permintaan untuk periode t, $\alpha$ merupakan faktor pembobot dengan nilai $(0<<1)$ dan $\mathrm{t}=$ nilai peramalan pada periode $\mathrm{ke}-\mathrm{t}$. Dengan rumus tersebut dapat digunakan untuk meramalkan nilai pada periode setelahnya dengan menggunakan data permintaan dan peramalan dari periode sebelumnya.

\section{Metode Holt}

Metode Eksponential Smoothing Adjusted for Trend atau yang biasa dikenal dengan Metode Holt merupakan metode yang digunakan ketika permintaan dipengaruhi oleh trend tetapi tidak dipengaruhi oleh musim [9]. Sehingga untuk meramalkan permintaan pada periode berikutnya, peneliti harus mengetahui ramalan dengan nilai penghalusan baru dan estimasi trend dengan menggunakan rumus berikut:

$$
\begin{aligned}
& L_{i}=\alpha Y_{i}+(1-\alpha)\left(L_{i}-1+T_{t-1}\right) \\
& T_{i}=\beta\left(L_{i}-L_{i-1}\right)+(1-\beta) T_{t-1}
\end{aligned}
$$

Nilai penghalusan baru ke $-\mathrm{t}$ memerlukan data permintaan $\mathrm{ke}-\mathrm{t}$ menggunakan nilai penghalusan dan nilai trend pada periode sebelumnya (rumus 2). Kemudian setelah mengetahui nilai penghalusan maka nilai trend dapat diketahui menggunakan rumus (3) diatas dengan $\alpha$ sebagai faktor bobot penghalusan untuk level $(0<\alpha<1)$ dan $\beta$ sebagai faktor bobot penghalusan untuk $(0<\beta<1)$. Setelah didapat hasil dari kedua rumus diatas, selanjutnya peneliti meramalkan permintaan sesungguhnya untuk periode yang akan datang menggunakan rumus berikut:

$$
\left.Y_{i+n}=L_{i}+\mathrm{n} T_{t}\right)
$$

Di mana: $L_{i}$ merupakan nilai dari penghalusan baru, $Y_{n}$ merupakan nilai permintaan dari periode $\mathrm{ke}-\mathrm{n}, T_{t}$ merupakan nilai trend pada periode $\mathrm{ke}-\mathrm{n}$, $Y_{i+n}$ merupakan peramalan untuk periode $\mathrm{ke}-\mathrm{n}$, dan $\mathrm{n}$ merupakan jumlah periode.

\section{PERANCANGAN SiSTEM}

Data yang didapatkan dari Badan Nasional Penanggulangan Bencana (BNPB) berisikan informasi jumlah kasus positif dari COVID-19. Dengan 100 hari pertama penyebaran COVID-19 di Indonesia sejak tanggal 2 Maret 2020 hingga 9 Juni 2020. Adapun langkah yang digunakan adalah sebagai berikut:

- Melakukan tinjauan pustaka mengenai Single Exponential Smoothing dan Double Exponential Smooting.

- Melakukan pengumpulan data jumlah kasus positif COVID-19 di Indonesia dari Gugus Tugas COVID-19 Indonesia.

- Melakukan training data menggunakan data 100 hari penyebaran COVID-19 untuk melihat persentase kesalahan.

- Melakukan pemeriksaan ketepatan model serta peramalan.

- Menganalisis serta mengambil kesimpulan. 


\section{HASIL DAN PEMBAHASAN}

Dengan menggunakan perangkat lunak MiniTab, data kumulatif kasus COVID-19 diolah dengan metode Single Exponential Smoothing menunjukkan hasil pada Tabel 1 berikut ini.

Tabel 1. Pengujian model pada metode Single Exponential Smoothing

\begin{tabular}{|c|c|c|c|c|c|c|c|c|c|}
\hline $\begin{array}{c}\boldsymbol{\alpha} \\
\text { (Alpha) }\end{array}$ & $\mathbf{0 . 1}$ & $\mathbf{0 . 2}$ & $\mathbf{0 . 3}$ & $\mathbf{0 . 4}$ & $\mathbf{0 . 5}$ & $\mathbf{0 . 6}$ & $\mathbf{0 . 7}$ & $\mathbf{0 . 8}$ & $\mathbf{0 . 9}$ \\
\hline MAPE & 42 & 28 & 22 & 18 & 15 & 13 & 13 & 10 & 9 \\
\hline MAD & 2674 & 1496 & 1037 & 794 & 643 & 541 & 541 & 410 & 366 \\
\hline MSD & 11598932 & 3508830 & 1670500 & 977397 & 642982 & 456177 & 456177 & 265464 & 212934 \\
\hline
\end{tabular}

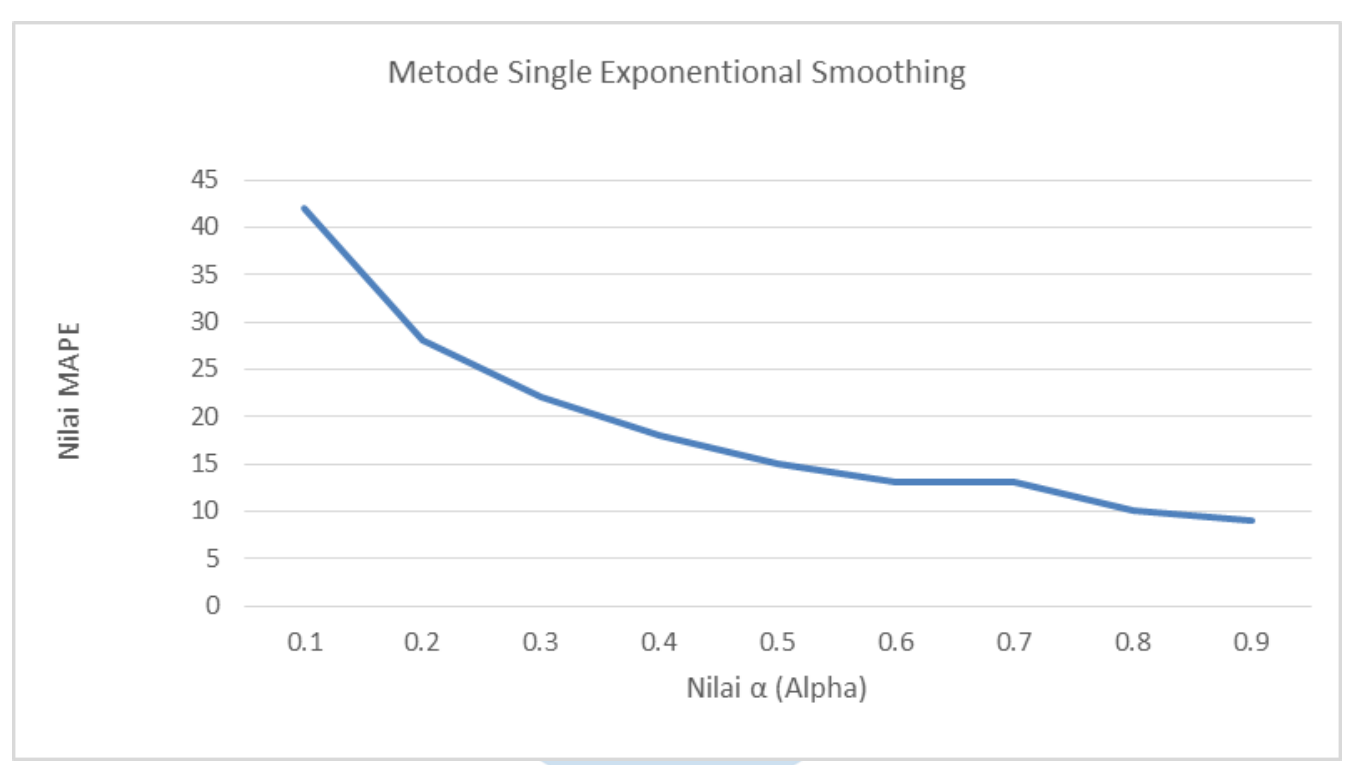

Gambar 1. Grafik nilai presentase terkecil (MAPE) pada Single Exponential Smoothing

Pada Gambar 1, grafik menunjukkan model terbaik yang didapatkan adalah pada nilai $($ Alpha $)=0.9$ dengan nilai MAPE 9, nilai MAD 366 serta nilai MSD 212934. Selanjutnya model dapat digunakan untuk melakukan peramalan pada 6 hari selanjutnya yang menghasilkan data pada Tabel 2 berikut ini.
Tabel 2. Hasil peramalan Single Exponential Smoothing dengan $($ Alpha $)=0.9$

\begin{tabular}{|c|c|c|c|}
\hline Period & Forecast & Lower & Upper \\
\hline 101 & 32962,5 & 32065,2 & 33859,7 \\
\hline 102 & 32962,5 & 32065,2 & 33859,7 \\
\hline 103 & 32962,5 & 32065,2 & 33859,7 \\
\hline 104 & 32962,5 & 32065,2 & 33859,7 \\
\hline 105 & 32962,5 & 32065,2 & 33859,7 \\
\hline 106 & 32962,5 & 32065,2 & 33859,7 \\
\hline
\end{tabular}




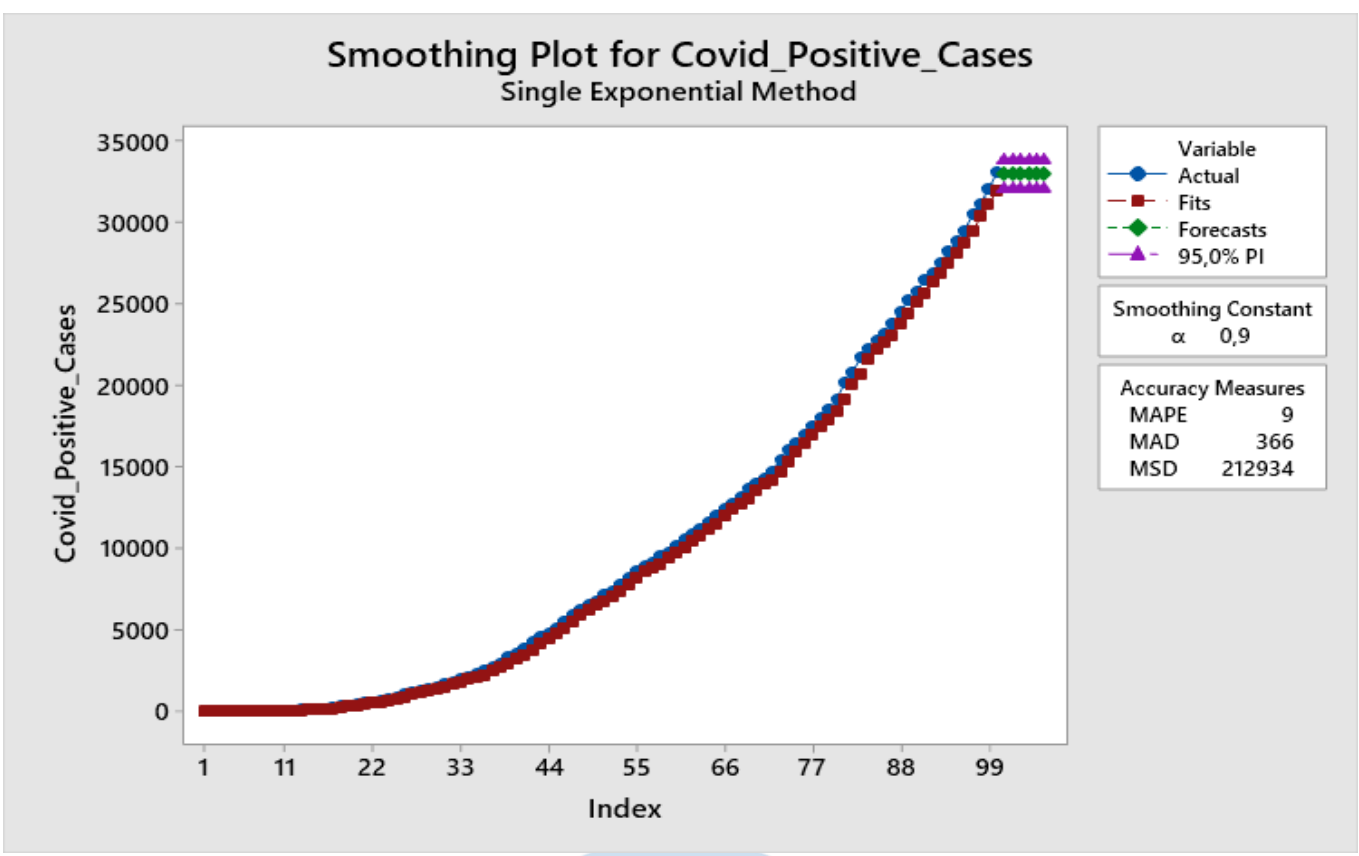

Gambar 2. Plot data hasil peramalan metode Single Exponential Smoothing

Hasil peramalan dengan menggunakan metode Single Exponential Smoothing Gambar 2 pada hari ke-101 sangat berdekatan dengan data asli, hari ke-102 sampai ke-106 menunjukkan nilai yang sama. Hal ini menunjukkan bahwa metode ini kurang sesuai jika digunakan untuk peramalan pada kasus COVID-19 ini.
Sedangkan dengan menggunakan metode Holt ditunjukkan pada Tabel 3.

Tabel 3. Pengujian model pada metode Holt

\begin{tabular}{|c|c|c|c|c|c|c|c|c|c|}
\hline $\boldsymbol{\alpha}$ (Alpha) & $\mathbf{0 . 1}$ & $\mathbf{0 . 2}$ & $\mathbf{0 . 3}$ & $\mathbf{0 . 4}$ & $\mathbf{0 . 5}$ & $\mathbf{0 . 6}$ & $\mathbf{0 . 7}$ & $\mathbf{0 . 8}$ & $\mathbf{0 . 9}$ \\
\hline $\boldsymbol{\beta}$ (Beta) & $\mathbf{0 . 1}$ & $\mathbf{0 . 2}$ & $\mathbf{0 . 3}$ & $\mathbf{0 . 4}$ & $\mathbf{0 . 5}$ & $\mathbf{0 . 6}$ & $\mathbf{0 . 7}$ & $\mathbf{0 . 8}$ & $\mathbf{0 . 9}$ \\
\hline MAPE & 10883 & 8257 & 7323 & 7014 & 7000 & 6357 & 6622 & 6669 & 6539 \\
\hline MAD & 1389 & 619 & 412 & 310 & 261 & 222 & 214 & 210 & 211 \\
\hline MSD & 2901125 & 1253960 & 859345 & 688305 & 604088 & 564779 & 557474 & 582903 & 654612 \\
\hline
\end{tabular}

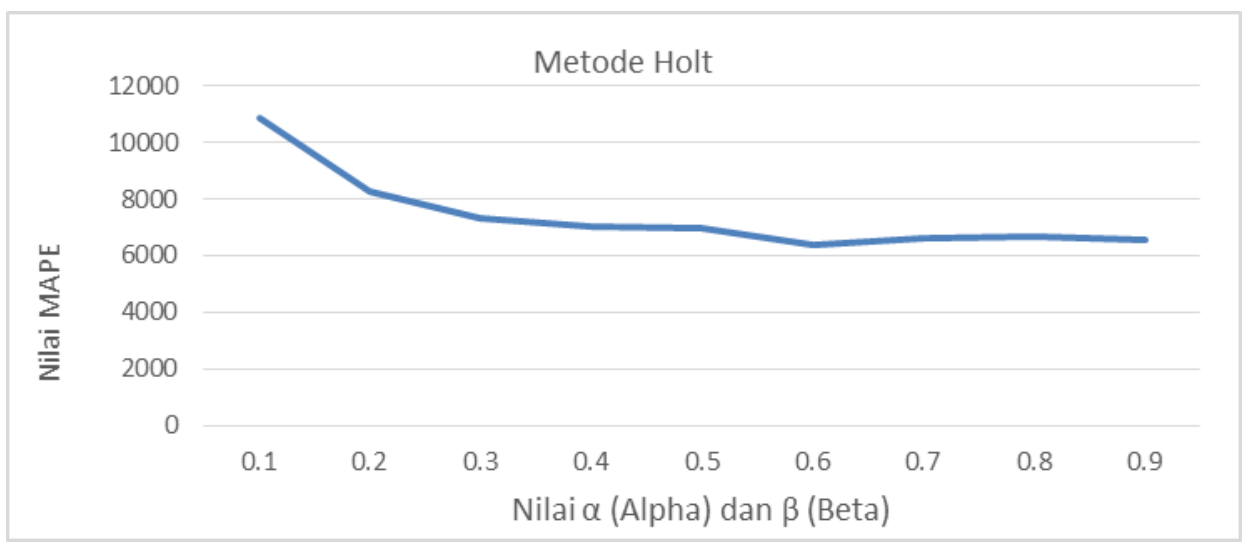

Gambar 3. Grafik nilai presentase terkecil (MAPE) pada metode Holt 
Dari grafik Gambar 3, menunjukkan model terbaik yang didapatkan adalah pada nilai $\alpha($ Alpha $)=0.6$ dan $\beta$ (Beta) $=0.6$ dengan nilai MAPE $=6357$, nilai MAD $=222$ serta nilai $\mathrm{MSD}=564779$. Selanjutnya model dapat digunakan untuk melakukan peramalan pada 6 hari selanjutnya yang menghasilkan data sebagai seperti pada Tabel 4 .
Tabel 4. Hasil peramalan Holt dengan $($ Alpha $)=0.6$

\begin{tabular}{|c|c|c|c|}
\hline Period & Forecast & Lower & Upper \\
\hline 101 & 33888,8 & 33344,2 & 34433,4 \\
\hline 102 & 34800 & 34150,2 & 35449,8 \\
\hline 103 & 35711,2 & 34946 & 36476,3 \\
\hline 104 & 36622,3 & 35735,5 & 37509,2 \\
\hline 105 & 37533,5 & 36521 & 38546 \\
\hline 106 & 38444,7 & 37303,8 & 39585,5 \\
\hline
\end{tabular}

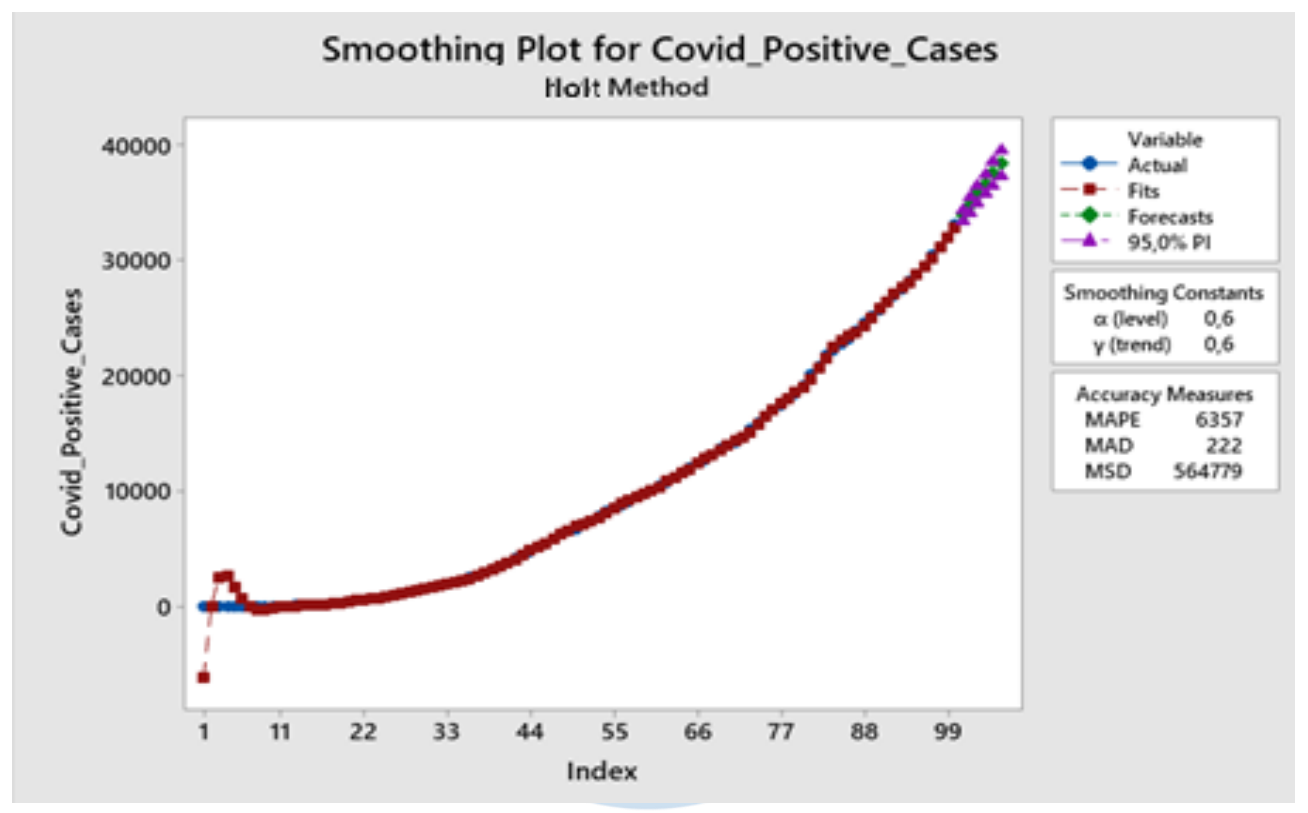

Gambar 4. Plot data hasil peramalan metode Holt

Hasil peramalan dengan menggunakan metode Holt dengan Alpha $=0.6$ dan Beta $=0.6$ yang ditunjukkan Gambar 4 pada hari ke-101 menunjukkan penambahan kasus menjadi 33888,8 kasus, tidak berimpitan dengan data actual hari ke-100 dan terus bertambah sampai hari ke-106 menjadi 38444,7 kasus, dengan MAPE $=6357, \mathrm{MAD}=222$, dan MSD $=564779$. Terlihat jumlah penambahan yang stabil terus bertambah. Hal ini terjadi karena pada metode Holt dapat membaca trend (Beta) data kasus yang terus bertambah dari kasus COVID-19. Dari hasil ini diharapkan dapat digunakan untuk menentukan strategi yang tepat sehingga dapat melewati masa kritis ini, dengan prediksi yang mendekati tepat maka kebijakan yang tepat juga dapat segera diambil.

\section{SimPULAN}

Peramalan dengan metode Single Exponential Smoothing dan metode Holt tidak cocok untuk meramalkan Jumlah Kasus COVID-19 di Indonesia. Karena menghasilkan nilai persentase kesalahan yang sangat besar. Kedua metode tersebut tidak cocok untuk meramalkan data jangka panjang. Namun, metode Holt menunjukkan hasil peramalan yang relatif lebih baik daripada Single Exponential Smoothing, karena metode Holt dapat membaca pola tren kasus penambahan pada kasus COVID-19 di Indonesia. Hasil prediksi ini diharapkan dapat digunakan dalam menentukan strategi yang tepat dalam penanganan wabah COVID-19 di Indonesia.

\section{DAFTAR PUSTAKA}

[1] A. J. Kucharski et al., "Early dynamics of transmission and control of COVID-19: a mathematical modelling study," Lancet Infect. Dis., vol. 20, no. 5, pp. 553-558, May 2020.

[2] Ratna Nuraini, "Kasus Covid-19 Pertama, Masyarakat Jangan Panik,” Indonesia.go.id, 2020. [Online]. Available: https://indonesia.go.id/narasi/indonesia-dalamangka/ekonomi/kasus-covid-19-pertama-masyarakatjangan-panik. [Accessed: 16-Jun-2020].

[3] S. Baharaeen and A. S. Masud, "A computer program for time series forecasting using single and double exponential smoothing techniques," Comput. Ind. Eng., vol. 11, no. 1-4, pp. 151-155, Jan. 1986.

[4] A. N. Aimran and A. Afthanorhan, "A comparison between single exponential smoothing (SES), double exponential smoothing (DES), holts (brown) and adaptive response rate exponential smoothing (ARRES) techniques in forecasting 


\section{ISSN 2085-4552}

Malaysia population," Glob. J. Math. Anal., vol. 2, no. 4, p. 276, Sep. 2014.

[5] A. Pranata, M. Akbar Hsb, T. Akhdansyah, and S. Anwar, "Penerapan Metode Pemulusan Eksponensial Ganda dan Tripel Untuk Meramalkan Kunjungan Wisatawan Mancanegara ke Indonesia," J. Data Anal., vol. 1, no. 1, pp. 32-41, Sep. 2018.

[6] X. Li, "Comparison and Analysis Between Holt Exponential Smoothing and Brown Exponential Smoothing Used for Freight Turnover Forecasts," in 2013 Third International Conference on Intelligent System Design and Engineering Applications, 2013, pp. 453-456.

[7] D. A. Pratama, A. L. Dzulfida, J. K. Huwaida, A. Prabowo, and A. Tripena, "Aplikasi Metode Double Exponential Smoothing Brown Dan Holt Untuk Meramalkan Total Pendapatan Bea Dan Cukai," in Prosiding Seminar Nasional Matematika dan Terapannya, 2016.

[8] F. Liantoni and A. Agusti, "Forecasting Bitcoin using Double Exponential Smoothing Method Based on Mean Absolute Percentage Error," JOIV Int. J. Informatics Vis., vol. 4, no. 2, pp. 91-95, Apr. 2020.

[9] A. Hartono, "Perbandingan Metode single Exponential Smoothing Dan Metode Exponential Smoothing Adjusted For Trend (Holt's Method) Untuk Meramalkan Penjualan. Studi Kasus: Toko Onderdil Mobil ‘Prodi, Purwodadi,'” $J$. EKSIS, vol. 5, no. 1, pp. 8-18, 2012.

[10] N. Kristanti and M. Y. Darsyah, "Perbandingan Peramalan Metode Single Exponential Smoothing dan Double Exsponential Smoothing pada Karakteristik Penduduk Bekerja di Indonesia Tahun 2017 Comparison of Forecasting Exsponential Smoothing and Double Exponential Smoothing Methods on the Popul," 2018. 